\section{Preservation of Hamocyanin}

THE hæmocyanins are important proteins since they contain a marker atom (copper) and are remarkably good antigens. Since other investigators may wish to prepare and preserve hæmocyanins, we wish to direct their attention to our observations. In the course of experiments with preparations from Busycon canaliculatum and Limulus polyphemus, we noted that the dry product obtained by lyophilization (freeze-drying) could not be dissolved in water, in 0.85 per cent seline or in Tyrode's solution $(p \mathrm{H} 3.0$ $11 \cdot 0$ ). The hæmocyanin had also lost its oxygenbinding capacity and no longer turned blue when exposed to air. On the other hand, we have kept serum containing hæmocyanin at $4^{\circ} \mathrm{C}$. under a layer of toluene, and find that it has retained antigenicity in guines pigs, rabbits and mice after as long as ten years storage.

\section{MORTIMER LitT}

Department of Bacteriology and Immunology,

Harvard Medical School.

\section{WIILIAM C. Boyd}

Department of Immunochemistry, Boston University School of Medicine.

\section{Detection of Polythionate in Cultures of Thiobacilli by Means of the Folin-Ciocalteu Reagent}

A substance giving a typical blue colour with the phospho-tungstate-phospho-molybdate reagent of Folin and Ciocalteu ${ }^{1}$ was found to accumulate in cultures of Thiobacillus thioparus and T. thiocyanoxidans growing in a medium containing thicsulphate. The component in question was not associated with the bacterial cells since it remained in the supernatant fluid of cultures centrifuged at high speeds. The possibility suggested itself that the materiel involved was an oxidation product of thiosulphate, possibly tetrathionate or one of the other polythjonates. These compounds have been reported to be intermediate oxidation products of thiosulphate by the Thiobacilli2.

Polythionate was found to form in cultures of both species when culture fluids were analysed by means of Starkey's qualitative test ${ }^{3}$. This test depends upon the action of potassium hydroxide on the polythionates, converting them to mixtures of thiosulphate and sulphite, products which can be estimated by titration with iodine. Increased titration values during the incubation of cultures would indicate in a general way an increase in the amount of polythionate. The formation of trithionate at the expense of the other polythionates would confound this observation, since this compound on treatment with potassium hydroxide gives a higher iodine titration than do the others. The production of the FolinCiocalteu reactive substance was found to parallel the accumulation of polythionate. This was especially noticeable in cultures of $T$. thiocyanoxidans, which failed to produce any reactive substance until late in the incubation period (Table 1).

Sodium tetrathionate was prepared according to the technique described by Partington and was purified by two recrystallizations from ethyl alcohol. The phenol reagent was readily reduced by the purified salt, which was very nearly as active in this
Table 1. Polythionath Accomulation In CDLTURES OF $T$. thiopames AND T. thiocyanoxidans $\triangle$ ND THE FORMATION

\begin{tabular}{|c|c|c|c|}
\hline Organism & $\begin{array}{c}\text { Incubation } \\
\text { (days) }\end{array}$ & Polythionate & $\begin{array}{c}\text { Optical density } \\
\text { of blue colour }\end{array}$ \\
\hline T. thioparus & 0 & 0 & $0 \cdot 00$ \\
& 3 & 40 & $0 \cdot 36$ \\
& 4 & 90 & $0 \cdot 53$ \\
$T$. thiocyanoxidans & 5 & 84 & $0 \cdot 60$ \\
& 7 & 69 & 0.51 \\
& 0 & 0 & $0 \cdot 00$ \\
& 3 & 0 & 0.00 \\
& 4 & 0 & $0 \cdot 00$ \\
& 5 & 15 & $0 \cdot 24$ \\
& 7 & 31 & 0.31 \\
\hline
\end{tabular}

* Expressed as microequivalents of iodine per $5 \mathrm{ml}$. of culture fluid. The cultures were grown in Roux bottles containing $50 \mathrm{ml}$. of medium ${ }^{2}$. Individual cultures were used for the daily analyses. The optical density measurements were made using the
spectrophotometer. Wave-length, $500 \mathrm{~m} \mu$.

capacity as tyrosine. Sulphite also reduced the reagent, but was considerably less active than tetrathionate (Table 2). If formalin were present during the reaction, the colour produced by sulphite was completely eradicated and the density of that produced by polythionate was reduced. The activities of these two substances differ from each other to such an extent as to make untenable the seemingly likely explanation that the mechanism involves the formation of sulphite from tetrathionate. That some alteration does occur was indicated by the necessity for the pre-incubation period in the alkaline copper solution of the usual Folin-Ciocalteu procedure.

Table 2. Relative Chromogenio Activity of Tyrosing, TetraTHONATE, SULPHITE AND CULTURE FLUID. EFFECT OF Formalin

\begin{tabular}{|c|c|c|}
\hline Sample & $\begin{array}{l}\text { Optical density of } \\
\text { Without formalin }\end{array}$ & $\begin{array}{l}\text { colour formed } \\
\text { With formalin }\end{array}$ \\
\hline $\begin{array}{l}\text { Tyrosine, } 0.5 \mu M \\
\text { Tetrathionate, } 1 \cdot 2 \mu M \\
\text { Sulphite, } 30 \mu M \\
\text { Culture fluid, } 1.0 \mathrm{ml} \text {. }\end{array}$ & $\begin{array}{l}0 \cdot 40 \\
0 \cdot 35 \\
0 \cdot 43 \\
0 \cdot 35\end{array}$ & $\begin{array}{l}0 \cdot 39 \\
0 \cdot 19 \\
0 \cdot 02 \\
0 \cdot 17\end{array}$ \\
\hline
\end{tabular}

The optical density was measured in the Klett-Summerson photometer, employing the No. 47 fllter. The culture fluid was a sample from a culture of $T$. thiocyanoxidans grown for five dsys in the usual thiosulphate medium, except that it contained a reduced concentration of phosphate. The medium after incubation was centrifuged for 30

The material formed in the culture fluids was found to behave toward formaldehyde in much the same way as tetrathionate; however, further work is needed to identify the culture material positively as a particular polythionate.

The use of the Folin-Ciocalteu reagent appeared to give an easy procedure for indicating the presence of polythionates in bacterial cultures. Its use for more quantitative purposes will require further study to determine the relative reactivity, if any, of the polythionates other than tetrathionate. Possibly alteration of the reagent and procedure would enhance its specificity.

\section{P. Prati*}

Department of Biochemistry,

University of Leeds.

\section{Feb. 24.}

* Present address: Department of Bacteriology, University of Florida, Gainesville.

1 Folin,Jo., and Ciocalteu, V., J. Biol. Chem., 73, 627 (1927)

$\checkmark$ Vishniac, W., and Santer, M., Bact. Rev., 21, 195 (1957).

s Starkey. R. L., J. Bact., 28, 387 (1934).

'Partington, J. R., "General and Inorganic Chemistry", 726 (Macmillan, London, 1951). 